\title{
Tarnita Polluted Area: Accumulation of Heavy Metals and Nutrients from the Soil by Woody Species
}

\author{
CARMEN IACOBAN ${ }^{2 *}$, IOAN MARIAN RISCA2, CATALIN ROIBU², ELENA TODIRASCU CIORNEA ${ }^{3}$, RADU NECULA ${ }^{4,5}$, \\ DARYA ILIEVA**, ION SANDU7,8, GABI DROCHIOIU4* \\ ${ }^{1}$ Marin Dracea National Institute for Research and Development in Forestry, Campulung Moldovenesc Station, 73 bis Calea \\ Bucovinei Str., 725100, Campulung Moldovenesc, Romania \\ ${ }^{2}$ Stefan cel Mare University of Suceava, Faculty of Forestry, 13 Universitatii Str., 720229, Suceava, Romania \\ ${ }^{3}$ Alexandru Ioan Cuza University of lasi, Faculty of Biology, 11 Carol I Blvd., 700506, Iasi, Romania \\ ${ }^{4}$ Alexandru Ioan Cuza University of lasi, Faculty of Chemistry, 11 Carol I Blvd., 700506, lasi, Romania \\ ${ }^{5}$ NIRDBS/Stejarul Biological Research Centre, 6 Alexandru cel Bun St., 610004, Piatra Neamt, Romania \\ ${ }^{6}$ University of Chemical Technology and Metallurgy, 8 Kl. Ohridski Blvd., Sofia, Bulgaria \\ ${ }^{7}$ Alexandru Ioan Cuza University of lasi, Arheoinvest Platform, Scientific Investigation Laboratory, 11 Carol I Blvd., 700506, Iasi, \\ Romania \\ ${ }^{8}$ Romanian Inventors Forum, 3 Sf. Petru Movila Str., Bloc L11, III/3, 700089 lasi, Romania
}

\begin{abstract}
Heavy metals are destructive environmental stressors that greatly reduce plant growth and productivity. Here, the content of some heavy metals ( $\mathrm{Fe}, \mathrm{Cu}, \mathrm{Zn}$ and $\mathrm{Mn}$ ) and mineral nutrients ( $\mathrm{Ca}$, Mgand $\mathrm{K}$ ) in silver fir (Abies alba Mill.) and European beech (Fagus sylvatica L.) wood from two sites in the Tarnika mining area (North-Est Romania) was analyzed. The first site (no. 1) is located near a big tailings dump, whereas the other one (no. 2) is situated $6 \mathrm{~km}$ South, in a less polluted area. The purpose of this work was to evaluate the present-date levels of such elements in the investigated biological materials and to compare them. Measurements of heavy metal content in wood were performed with an AAS flame spectrometer, whereas an ICP-OES spectrometer was used for soil and tailings dump samples. The Mn content was higher in the site no. 1 located near the dump, for both species, but the difference was statistically significant only for the European beech trees. The Zn content of samples from the site no. 1 was lower than that corresponding to the second one (no. 2) for both species, but significant for the silver fir only. However, there was not found a significant difference in respect to both iron and copper in the samples collected from the two species and two different sites. Furthermore, the content of $\mathrm{Ca}$ and $\mathrm{Mg}$ of both species was found higher for the site no. 2 , suggesting a better state of nutrition of the investigated trees than of those located near the tailings dump. The content of calcium and magnesium of silver fir was negatively correlated with the diameter of the trees collected from both sites.
\end{abstract}

Keywords: mining area, heavy metal accumulation, silver fir, European beech, mineral nutrients

Heavy metal pollution around the closed mines is an increasing environmental concern worldwide [1]. Generally, the major pollutants of the environmentare taken by plants taking from the soil and they can reach the human and animal organisms where they induce a severe imbalance, which is seen as the accumulation of free oxygen radicals with direct repercussions on the synthesis and increase in the activity of antioxidant enzymes [2]. Indeed, heavy metal pollution affects much the antioxidant potential of various plants. Thus, a close correlation between the concentration of vitamin C, carotenes, polyphenols, total carbohydrates and total soluble proteins and the activity of the oxidative stress enzymes (superoxide-dismutase, catalase, peroxidase, isocitrate-dehydrogenase, ketoglutarate-dehydrogenase, succinate-dehydrogenase and malate-dehydrogenase) was found in Rosa canina L. samples collected from the heavy metals and arsenic polluted area around of Tarnita closed mine [3].

Important changes in the concentration of cuticular alkane of tall fescue plants ( Festuca arundinacea) induced by the presence of heavy metal ions was also recently reported [4]. These authors showed that multiple mechanisms may exist through which the tested plants could develop and adapt when exposed to various chemicals characterized by different degrees of toxicity. Thus, significant differences were observed between the results from $\mathrm{Ba}^{2+}, \mathrm{Pb}^{2+}$ and $\mathrm{Fe}^{2+}$ and those with $\mathrm{AsO}_{4}{ }^{3-}$ and $\mathrm{Cu}^{2+}$, and these ions are characterized by different degrees of toxicity. However, most of heavy metal ions react with thiol-containing peptides and proteins, which may protect the cells against metal toxicity [5]. The well-known metal scavengers are glutathione and metallothioneins.

Environmental pollution with heavy metals around the barite closed mine of Tarnipa does represent high risks to the public health in Eastern Carpathians, being also an intensively studied issue [6-12]. There are also some other similarly contaminated areas in Romania such as Copoa Micã, Baia Mare and Zlatna [13-17]. The Le-u Ursului copper mine and the copper and barite processing factory from Tarnika, are situated near the Ostra village/South-west of Suceava County (fig. 1). The mining and processing activity were stopped in 2006. Nevertheless, this zone with a very intense nonferrous mining activity have been much analysed because the pollution is still very high. Thus, the individual health and radial growth of spruce trees (Picea abies) in Tarnika area, Suceava County, North-East Romania was investigated [18]. The main factors and processes that could lead to the pollution of the environment have also been identified [8]. The accumulation of metal ions by plants occur in two steps: one assumes binding to negatively charged groups on the cell surface and the passive transport of metal ions across the cell wall during

*emails: carmeniacoban@ymail.com, darjailieva@abv.bg, gabidr@uaic.ro 
a short time, whereas the other involves the penetration of the cell membrane and the bioaccumulation of the metal ions onto the protoplasts [19-21].

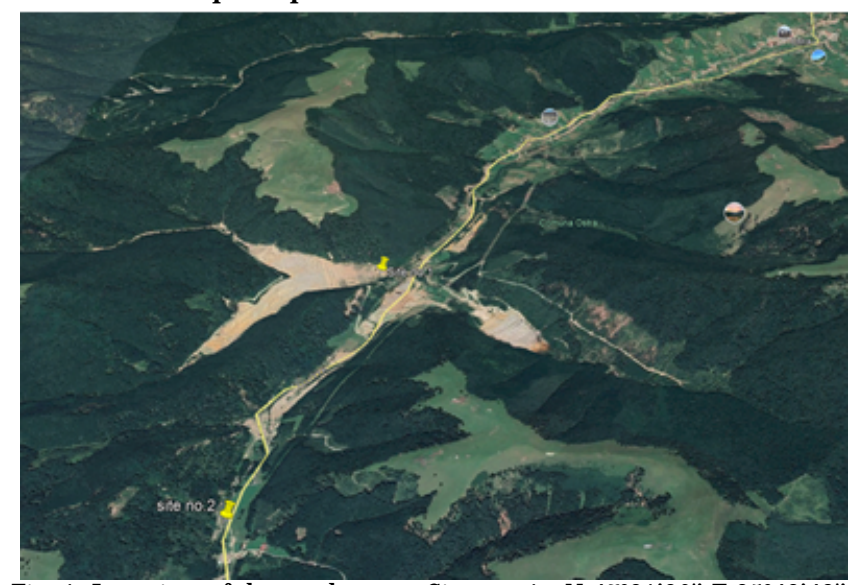

Fig. 1. Location of the study area: Site no. 1 - N 47'21'36" E $25^{\circ} 42^{\prime} 42^{\prime \prime}$ 826 (m.a.sl.) and Site no. 2 - N 47²0'22' E 2542'24" 881 (m a.s.I.) (considered as a less polluted area)

Here, we report on the accumulation and the effect of heavy metals ( $\mathrm{Fe}, \mathrm{Cu}, \mathrm{Zn}$ and $\mathrm{Mn}$ ) in two species of trees: silver fir (Abies alba Mill.) and European beech (Fagus sylvatica L.). According to the Environmental Agreement for closing and greening the mine Le- $u$ Ursului, U.P. Tarnikg, Suceava County of 2014, the content of Fe, Mn, Cu and Zn in the water from the river Valea Straja were higher than the limits admitted by Min. Ord. 161 (2006) [22]. This was the incentive reasons to determine such heavy metals in the wood cores. At the same time the content of mineral nutrients in the wood was analyzed to establish if the pollution has any influence on nutrients uptake. Because larger trees have deeper roots and may be less affected by soil pollution with heavy metals, it was considered to be justified analyzing the variation in the content of metals and nutrients in wood, depending on the diameter of the trees.

\section{Experimental part}

Materials and methods

Site location. In order to conduct the research, two sites located on the Tarnita mining area, Suceava County (Romania), were selected (fig. 1). One of them (Site no. 1 - N 47021'36" E $25^{\circ} 42^{\prime} 42^{\prime \prime}$ ) is located near a big tailings dump, resulted from processed ores, being considered as a highly polluted site, whereas the second one is situated 6

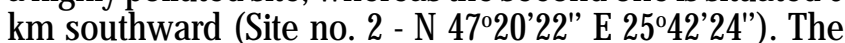
second site was first considered as an unpolluted area and lately as a less polluted zone. Both of them are located within mixed forests (59\% Norway spruce, $22 \%$ silver fir, $18 \%$ European beech and $1 \%$ other deciduous species). Reagents

All reagents were of analytical grade and solutions were prepared with millQ-grade water (Millipore system, Bedford, MA). Inorganic salts were purchased from Merck (Darmstadt, Germany) or Sigma-Aldrich (USA).

\section{Sampling}

The wood samples were collected in September, 2015. From each site, five trees of silver fir and five trees of European beech were taken for sampling. The whole core samples (from the bark to the pith) were taken with a Pressler drill, at $1.3 \mathrm{~m}$ height. It was considered that the entire core would be used for sample preparation and analysis, because some authors concluded that the radial distribution patterns of heavy metals in wood should be carefully used as a tool for chronological record of environmental pollution [23]. It was also stated that peaks of heavy metals are apparently mobile in the stem wood [24].

\section{Chemical analysis}

After drying at $80^{\circ} \mathrm{C}$ to constant weight, the entire cores were cut into small chips and grounded with a Retsch mill MM400, for $2.5 \mathrm{~min}$, with a frequency of $30 \mathrm{~Hz}$, in order to provide homogeneous samples. From the resulted samples of powder, amounts of $0.5 \mathrm{~g}$ were weighed and dry burnt for decomposition (Dry-ashing methods). The dry ashing method used for wood samples mineralization was similar to that described in literature for precise and accurate determination of trace elements in biological and environmental materials $[25,26]$. The AAS measurements of heavy metals and mineral nutrient concentrations in the biological material were performed on a Perkin-Elmer Analyst 700 atomic absorption spectrometer with deuterium background corrector. Perkin-Elmer singleelement hollow cathode lamps were used and all measurements were carried out in an air/acetylene flame. In order to assure the quality of results, a sample of vegetal material of known and verified concentrations (from the $17^{\text {th }}$ Needle/leaf inter-laboratory test 2014/2015, ICP Forests) was analyzed within the same series with the wood samples.

The heavy metal content in tailing and soil samples of Tarnita was determined by a dual viewing Inductively Coupled Plasma - Optical Emission Spectroscopy (ICPOES), using an Optima 5300DV spectrometer (PerkinElmer, Waltham, MA, USA), which was coupled with the ultrasonic nebulizer CETAC 6000AT + (CETAC, Omaha, NE, USA). Thus, samples of 0.2-0.3 g were extracted with a boiling mixture of $\mathrm{HNO}_{3}$ and $\mathrm{HCl}(1: 3 \mathrm{v} / \mathrm{v})(15 \mathrm{~mL})$ for $25 \mathrm{~min}$ in a beaker covered with a watch glass. Then, the extract was filtered, diluted up to $50.0 \mathrm{~mL}$ with distilled water, and analyzed by ICP-OES.

The UV-Vis measurements were performed using a LIBRA S35 PC UV/Vis spectrophotometer, in quartz cuvettes with a path length of $1 \mathrm{~cm}$ against the control carried out only with the reagents. Centrifugation was performed using a Hettich centrifuge Mikro 22R (from Andreas Hettich $\mathrm{GmbH} \&$ Co. KG, Tuttlingen, Germany). Ultrasonic extraction of heavy metals from soils and sterile dump material was performed with an ultrasonic water bath (from JP Selecta its Barcelona, Spain).

\section{Statistical analysis}

The five trees of each species selected on each site were considered as replications and the obtained data were treated as independent samples. The normality of distributions was tested using Shapiro-W ilk test, while the equality of variances was tested with Levene's test. When the distribution was normal, the differences between means were tested using Student's $t$ test, considering the equality or inequality of variances. For abnormal distribution, the nonparametric Mann-Whitney U test [27] was used. Standard deviation of triplicate values was calculated for each determination of heavy metals in the environmental samples.

\section{Results and discussions}

Environmental samples were collected both from tailings dumps and near Tarnicioara River as reported previously [28]. High concentrations of heavy metals were found in the soils in the neighborhood of the tailing dumps, ponds as well as in the annual plants known as bioindicators. To describe the contamination of the region 
we applied the following scheme of analysis: dumpsurrounding soils and waters-plants. Being considered as long-term pollution sensors and archivists, the trees pointed out by several authors, as summarized by Pundytë et al. [29]. The steps of their research follow the scheme: analysis of soils, and then analysis of wood trees in the observed region. Our methodology has followed the same approach. Tarnita pollution case assessment has been investigated in a number of previous works [30,31]. In our experiments, large amounts of $\mathrm{Fe}, \mathrm{Cu}, \mathrm{Pb}, \mathrm{Zn}$ and less $\mathrm{Cr}$, $\mathrm{Mn}, \mathrm{Cd}, \mathrm{Ni}$ and $\mathrm{As}$, as well as nutrients $\mathrm{Na}, \mathrm{Ca}, \mathrm{K}$ and $\mathrm{Mg}$ were measured in the soils around tailings dumps. The accumulation of metals was studied in Silver fir w ood and European beech wood. Samples were collected from two regions the around the tailings dump: No. 1-highly polluted site and No. 2 - less polluted area. The samples were prepared for digestion by the dry-ashing method. The method of choice is relatively simpler and safer than the wet-digestion methods, although itcan introduce volatility with respect to phosphorous (P), potassium (K), sulfur (S), arsenic (As), selenium (Se) and mercury $(\mathrm{Hg})$ [32]. Moreover, this method has been preferred over the wet digestion because it requires smaller amounts of reagents and, therefore, gives lower blanks for most elements as well as better recovery. Results calculated as $\mathrm{mg} / \mathrm{kg}$ are presented as mean \pm SD $(n=3,95 \%)$ in tables 1 and 2 . The variations of metals content as a function of tree diameter was shown in figure 2.

The analysis of the wood core of the two-tree species collected from the vicinity of the polluted site no. 1 and from a less polluted one situated $6 \mathrm{~km}$ far from the first one showed high concentrations of $\mathrm{Fe}, \mathrm{Cu}, \mathrm{Zn}$ and $\mathrm{Mn}$, although both fir and beech are demanding species to environmental condition as it was described at investigations of individual health and radial growth of trees in Tarnita area [18]. Therefore, this anthropogenic influence exceeds permissible value of heavy metal content in soils caused major disruptions to their quality. The analysis of other authors of biochemical properties of the species from different polluted areas of Suceava County showed that the range of antioxidant responses to the pollution conditions at Tarnita and other sites was different, depending on the type of pollutant interference in the environment [9]. Thus, the metal ions resulting from polymetallic sulfide alteration in Tarnita were able to inhibit the activity of SOD in Picea abies L.
Heavy metal concentration in wood samples decreased in the order: $\mathrm{Fe}>\mathrm{Mn}>\mathrm{Zn}>\mathrm{Cu}$ for fir trees, at both sites and in the order: $\mathrm{Mn}>\mathrm{Fe}>\mathrm{Zn}>\mathrm{Cu}$ for beech trees sampled at the two sites (Table 1). As for the other elements, the order was: $\mathrm{K}>\mathrm{Ca}>\mathrm{Mg}>\mathrm{Na}$. There was found no significant difference between the trees from the two sites, except the case of content of $\mathrm{Zn}$ in the silver fir wood and $\mathrm{Mn}$ in the European beech wood (table 2). For European beech, the manganese content measured on the site no. 1 (more polluted) was twice higher than that on the site no. 2 (considered as less polluted). In the case of silver fir, the content was also almost two times higher when measured on the site no. 1.

The comparison of the results from the fir samples with those from beech denoted that: (i) the two species showed approximately the same concentrations of heavy metals and mineral nutrients in their wood, except for iron ions (Fe) from the less polluted site and magnesium $(\mathrm{Mg})$ in the more polluted site (table 2); (ii) Silver fir trees had about twice the concentration of Fe than that of European beech wood, while the beech trees had about three times more $\mathrm{Mg}$ than silver fir tree.

The mean content of $\mathrm{Zn}$ in our study was lower in the case of site no. 1, whereas in the case of site no. 2 it was close to the value registered in the non-polluted area. Similar results issued from a study conducted in Poland on Quercus robur L. [33], in which the authors reported contents of $0.63 \mathrm{mg} / \mathrm{kg} \mathrm{Cu}$ and $7.50 \mathrm{mg} / \mathrm{kg} \mathrm{Zn}$ in wood on an unpolluted area. For two other sites, located in areas polluted with $\mathrm{Cu}, \mathrm{Pb}$ (in Glogow) and $\mathrm{Zn}, \mathrm{Pb}, \mathrm{Cd}, \mathrm{Cu}$ (in Zawiercie), the content of $\mathrm{Cu}$ and $\mathrm{Zn}$ as determined by AAS was 15.2 and 12.8, as well as 1.01 and 26.0, respectively. The mean content of $\mathrm{Cu}$ in fir and beech wood was twice than in Zawiercie, but lower than in Glogów.

The variation of the heavy metal content of the fir tree as a function of the tree diameter was specific for any chemical element considered. Although $\mathrm{Fe}$ and $\mathrm{Cu}$ were not found to have an ascending or descending trend, there was a tendency for Mn growth, and a decrease for Zn as the tree diameter increased (table 3). A statistically significant correlation was found only in the case of zinc.

Nevertheless, our results were similar to those from other studies on conifer species (for example, pine trees [34]). We also found a large variation in the heavy metal concentrations between individual trees, as other studies have revealed [35, 36]. Rothpfeffer and Karltun (2007)

Table 1

HEAVY METALS CONTENTS IN THE STEM WOOD OF SILVER FIR AND BEECH TREES GROWING ON THE POLLUTED SITE (No.1) AND LESS POLLUTED ONE (No. 2)

\begin{tabular}{|c|c|c|c|c|c|}
\hline Species & Type of site & \multicolumn{3}{|c|}{ Concentrations of heavy metals (mg kg $\left.{ }^{-1}\right)$} \\
\cline { 3 - 6 } & & Fe & Mn & Zn & Cu \\
\hline Silver fir & Less polluted & $85.18 \pm 21.76^{\mathrm{A}}$ & $33.00 \pm 10.09^{\mathrm{A}}$ & $6.61 \pm 0.76^{\mathrm{2}}$ & $2.86 \pm 0.85^{\mathrm{a}}$ \\
& More polluted & $65.54 \pm 21.58^{\mathrm{A}}$ & $60.21 \pm 45.42^{\mathrm{A}}$ & $4.29 \pm 0.89^{\mathrm{b}}$ & $2.85 \pm 1.08^{\mathrm{a}}$ \\
\hline $\begin{array}{c}\text { European } \\
\text { beech }\end{array}$ & Less polluted & $45.05 \pm 4.60^{\mathrm{A}}$ & $45.42 \pm 25.40^{\mathrm{A}}$ & $6.23 \pm 2.12^{\mathrm{A}}$ & $2.46 \pm 2.22^{\mathrm{A}}$ \\
\hline
\end{tabular}

Note: Means followed by the same letter are not significantly different at $\alpha=0.05$ (small letters t-test for two independent samples; capital letters - Mann-Whitney U test).

Table 2

THE MINERAL CONTENT OF THE STEM WOOD OF SILVER FIR AND BEECH TREES GROWING ON THE TWO DIFFERENT SITES

\begin{tabular}{|c|c|c|c|c|c|}
\hline \multirow[t]{2}{*}{ Species } & \multirow[t]{2}{*}{ Type of site } & \multicolumn{4}{|c|}{ Concentrations of heavy metals (mg kg${ }^{-1}$ ) } \\
\hline & & $\mathrm{Ca}$ & $\mathrm{Mg}$ & $\mathrm{K}$ & $\mathrm{Na}$ \\
\hline \multirow[t]{2}{*}{ Silver fir } & Less polluted & $1092 \pm 243^{\mathrm{A}}$ & $170.3 \pm 8.9^{A}$ & $1222 \pm 370^{\mathrm{a}}$ & $48.2 \pm 24.8^{3}$ \\
\hline & More polluted & $856=144^{x}$ & $108.5 \pm 21.5^{\mathrm{A}}$ & $1216 \pm 284^{i}$ & $55.2 \pm 26.4^{\mathrm{a}}$ \\
\hline \multirow{2}{*}{$\begin{array}{c}\text { European } \\
\text { beech }\end{array}$} & Less polluted & $1110 \pm 203^{\mathrm{a}}$ & $309.7 \pm 113.7^{2}$ & $1110 \pm 328^{\mathrm{a}}$ & $32.3 \pm 7.7^{\mathrm{s}}$ \\
\hline & More polluted & $1066 \pm 423^{\mathrm{a}}$ & $295.8=69.8^{2}$ & $1355=195^{\mathrm{a}}$ & $31.4 \pm 18.4^{\mathrm{a}}$ \\
\hline
\end{tabular}

Note: Means followed by the same letter are not significantly different at $\alpha=0.05$ (small letters t-test for two independent samples; capital letters - Mann-Whitney U test). 
Table 3

COMPARISON OF TREE SPECIES WITH RESPECT TO HEAVY METAL CONTENT

\begin{tabular}{|c|c|c|c|c|c|}
\hline \multirow[t]{2}{*}{ Type of site } & \multirow[t]{2}{*}{ Species } & \multicolumn{4}{|c|}{ Concentrations of heavy metals (mg kg-1) } \\
\hline & & $\mathrm{Fe}$ & $\operatorname{Mn}$ & $\mathrm{Zn}$ & $\mathrm{Cu}$ \\
\hline \multirow[t]{2}{*}{ Less polluted } & Silver fír & $85.2 \pm 21.8^{2}$ & $33.0 \pm 10.1^{3}$ & $6.61 \pm 0.76^{\mathrm{a}}$ & $2.86 \pm 0.85^{\mathrm{A}}$ \\
\hline & European beech & $45.1 \pm 4.6^{6}$ & $45.4 \pm 25.4^{a}$ & $6.23=2.12^{\mathrm{a}}$ & $2.46=2.22^{4}$ \\
\hline \multirow[t]{2}{*}{ More polluted } & Silver fír & $65.5 \pm 21.6^{\mathrm{A}}$ & $60.2 \pm 45.4^{3}$ & $4.29=0.89^{\mathrm{A}}$ & $2.85 \pm 1.08^{\mathrm{a}}$ \\
\hline & European beech & $58,4 \pm 19,9 \mathrm{~A}^{-}$ & $99.1 \pm 20.2^{\mathbf{a}}$ & $3.95=2.74^{4}$ & $1.70 \pm 0.31^{\mathrm{a}}$ \\
\hline
\end{tabular}

Note: Means followed by the same letter are not significantly different at $\alpha=0.05$ (small letters t-test for two independent samples; capital letters - Mann-Whitney U test).

Table 4

COMPARISON OF TREE SPECIES IN TERMS OF MINERAL NUTRIENT CONTENT

\begin{tabular}{|c|c|c|c|c|c|}
\hline \multirow[t]{2}{*}{ Type of site } & \multirow[t]{2}{*}{ Species } & \multicolumn{4}{|c|}{ Concentrations of nutrients and $\mathrm{Na}\left(\mathrm{mg} \mathrm{kg}{ }^{-1}\right)$} \\
\hline & & $\mathrm{Ca}$ & $\mathrm{Mg}$ & $\mathrm{K}$ & $\mathrm{Na}$ \\
\hline \multirow[t]{2}{*}{ Less polluted } & Silver fir & $1092 \pm 243^{M}$ & $170.3 \pm 8.9^{\mathrm{a}}$ & $1222 \pm 370^{2}$ & $48.2 \pm 24.8^{3}$ \\
\hline & European beech & $1110 \pm 203^{x}$ & $309.7 \pm 113.7^{\mathrm{a}}$ & $1110 \pm 328^{2}$ & $32.3 \pm 7.7^{\mathrm{a}}$ \\
\hline \multirow[t]{2}{*}{ More polluted } & Silver fir & $856 \pm 144^{2}$ & $108.5 \pm 21.5^{\mathrm{a}}$ & $1216 \pm 284^{3}$ & $55.2 \pm 26.4^{\mathrm{s}}$ \\
\hline & European beech & $1066 \pm 423^{3}$ & $295.8=69.8^{\circ}$ & $1355 \pm 195^{2}$ & $31.4 \pm 18.4^{3}$ \\
\hline
\end{tabular}

Note: Means followed by the same letter are not significantly different at $\alpha=0.05$ (small letters t-test for two independent samples; capital letters - Mann-Whitney U test).

found for Picea abies that $\mathrm{Ba}, \mathrm{Cd}$ and $\mathrm{Pb}$ in wood and $\mathrm{Ba}$, $\mathrm{Ca}, \mathrm{Cd}, \mathrm{Co}, \mathrm{Mn}, \mathrm{Sr}$ and $\mathrm{Zn}$ in bark were significantly and positively correlated to diameter, while negative correlations for $\mathrm{Cu}, \mathrm{Fe}, \mathrm{K}, \mathrm{Mg}$ and $\mathrm{P}$ were found in wood and for $\mathrm{Cr}, \mathrm{Cu}, \mathrm{Fe}, \mathrm{K}, \mathrm{Na}$, Ni and $\mathrm{P}$ in bark [34]. In the present study, the content of $\mathrm{Ca}$ and $\mathrm{Mg}$ in the entire cores (wood and bark) was negatively correlated and statistically significant with the tree diameter for the Abies alba trees sampled from the sites No. 1 and No. 2.

Among the mineral nutrients, $\mathrm{Mg}$ and $\mathrm{Ca}$ showed a decreasing trend, while $\mathrm{Na}$ and $\mathrm{K}$ concentrations tended to increase with the tree diameter increasing (table 4). In the case of the first two elements, the intensity of the relationship is average and statistically significant (fig. 2). The correlation coefficient $r$ for various types of regression equations (linear, exponential, logarithmic, polynomial and others) was also calculated. The concentrations of $\mathrm{Ca}$ and $\mathrm{Mg}$ decreases logarithmically with the diameter of fir tree, although a polynomial regression equation seems to describe better the relationship between $\mathrm{Mg}$ content and the core diameter as the correlation coefficient showed. Also, for $\mathrm{Zn}$ dependence content of core diameter, both a logarithmic equation and polynomial one was calculated.

Environmental pollution with heavy metals poses a major risk to areas located near mining and ores exploitation enterprises around the world. We have determined the content of some heavy metals ( $\mathrm{Fe}, \mathrm{Cu}, \mathrm{Zn}$ and $\mathrm{Mn}$ ) and three mineral nutrients ( $\mathrm{Ca}, \mathrm{Mg}$ and $\mathrm{K}$ ) in the wood core of two tree species collected from the vicinity of a polluted site and from a less polluted one situated 6 $\mathrm{km}$ far from the first one in the Tarnita mining area (fig. 1). The individual health and radial growth of spruce trees ( Picea abies) in Tarnita area have also been studied [18]. In our experiments, we used the dry-ashing method because it is relatively simpler and safer than wet-digestion methods, although it can introduce volatility with respect to phosphorous $(P)$, potassium (K), sulfur (S), arsenic (As), selenium (Se) and mercury ( $\mathrm{Hg})$ [28]. Moreover, this method has been preferred over the wet digestion because it requires smaller amounts of reagents and, therefore, gives lower blanks for most elements and better recovery. Previously, we have determined the content of heavy metals and mineral nutrients in various samples collected from both the tailings dumps, soil around these dumps and near the Tarnicioara River [28]. In addition, we have demonstrated that the annual plants are contaminated mostly by the metal ions found in the soil in the neighborhood of tailings dumps and ponds. The results reported here demonstrate that $\mathrm{Fe}, \mathrm{Cu}$ and $\mathrm{Zn}$ contents in collected cores are higher for fir trees than for beech ones collected from both sites, which is in good agreement with the observation that conifers generally have higher heavy metal content than the deciduous species, confirming thus the results by other authors [37]. The Mn content was higher in beech than in fir, regardless of site. On the other hand, deciduous trees generally accumulate more minerals than evergreen trees. The uptake of heavy metal and macronutrient fluxes has also been studied in Pinus sylvestris L. wood [29]. We followed here the research methodology used by Pundytë et al. (2011) and have achieved quite similar results in the case of Tarnita closed mine area.

The concentrations of macronutrients, expressed as mg/ $\mathrm{kg}$, in sapwood and heartwood of Fagus sylvatica were 1100 and 950 for potassium, 700 and 850 for calcium, 180 and 225 for magnesium, respectively [38]. The average concentrations for the entire cores analyzed in the present study were higher for all macronutrients measured in both sites (no. 1 and no. 2: 1110 and 1355 for K, 1066 and 1110 for $\mathrm{Ca}, 310$ and 296 for $\mathrm{Mg}$ ).

Taken together, our results can help explain the effect on the physiological processes of the forest trees of the heavy metal ions and their spread. Previously, some authors have emphasized the risk of wind-driven removal and transport of the waste from the surface of tailings ponds and dumps, given that fine grains prevail [8]. Indeed, several metal ions accumulated similarly in wood cores regardless of the distance from the tailing dump, suggest that the heavy metal pollution acts through different mechanisms in trees over annual plants. The tailings removal through mechanical transport by water, during heavy rainfall, and the appearance of hydrated sulfates on the rock fragments from the mining waste affect mostly annual species. In addition, sulfates are highly susceptible to the generation of acid mine drainage, accumulation of heavy metal ions in the soils around the tailings dumps, and then in seeds and roots.

The investigated woody species seem to react against heavy metal pollution dependent on various metal ion concentrations as shown by our experiments. Iron is less accumulated in wood core in much polluted area than manganese, while $\mathrm{Ca}$ and $\mathrm{Mg}$ concentrations decreased, suggesting that heavy metals ( $\mathrm{Pb}, \mathrm{Cd}, \mathrm{Cu}, \mathrm{Zn}$, As, etc.) and other factors like $\mathrm{pH}$, the presence of some anions etc., 

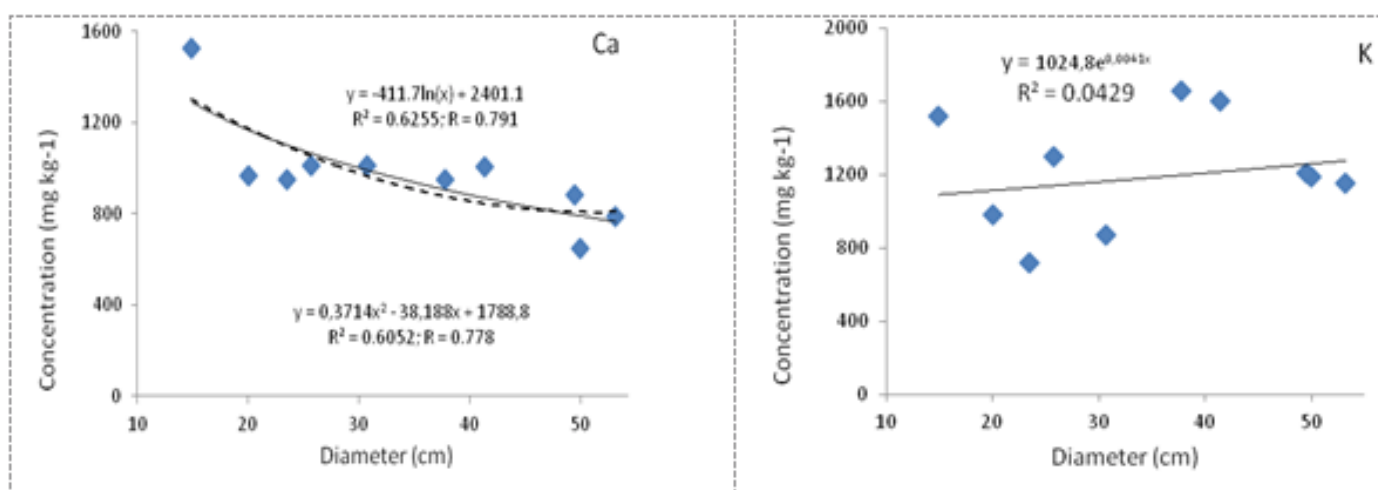

Fig. 2. Variation with tree diameter of zinc, calcium, potassium, and magnesium
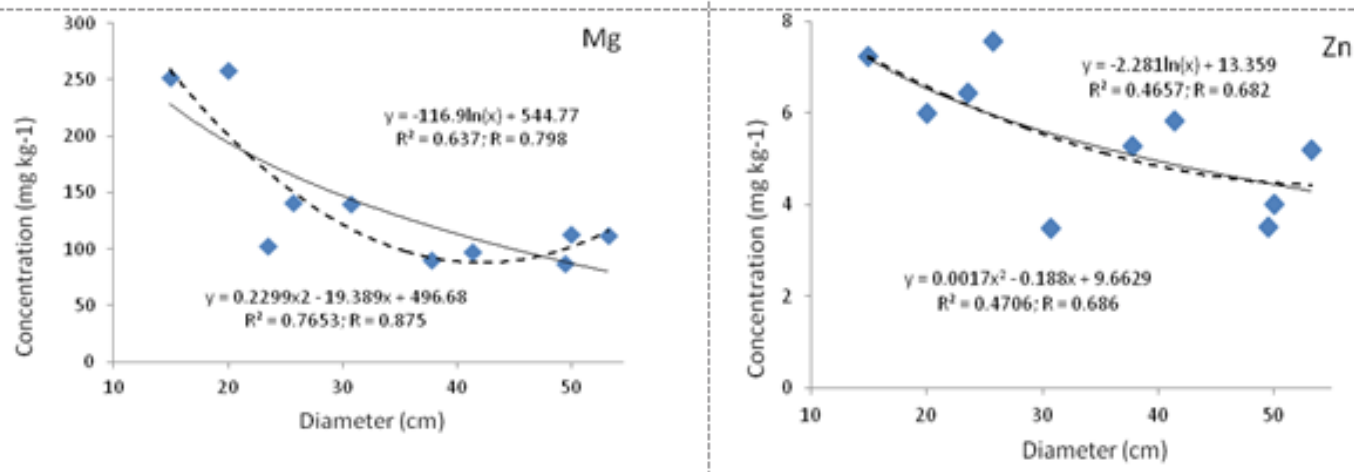
content in the wood core of the silver fir trees

can affect deeply the physiological processes of the investigated plants.

Heavy metal content of one of the tailing dumps, the most pollutant agent in that area, as well as the soil samples collected $30 \mathrm{~m}$ far from the sterile dump, and expressed as $\mathrm{mg} / \mathrm{kg}$, showed different patterns of metal ion accumulation. According to our ICP-OES measurements, cadmium content ranged between $7-13 \mathrm{mg} / \mathrm{kg}$ in tailing dumps and $<0.5 \mathrm{mg} / \mathrm{kg}$ in the surrounding soils. However, even very toxic, some other metals were found in Tarnita forest area like iron, copper, and lead. Arsenic was also high enough both in the tailing dump and around it. The most toxic elements found in the sterile dump were copper $(3,119 \mathrm{mg} / \mathrm{kg})$, lead $(2,672 \mathrm{mg} / \mathrm{kg})$, and arsenic $(676 \mathrm{mg} /$ $\mathrm{kg}$ ), whereas the other elements are either less toxic (Ba, $\mathrm{Zn}$ ) or were present as minor elements. Interestingly, at only $30 \mathrm{~m}$ far from the tailing dump, we found $334 \mathrm{mg} / \mathrm{kg}$ copper, $137 \mathrm{mg} / \mathrm{kg}$ lead and $96 \mathrm{mg} / \mathrm{kg}$ arsenic. These data suggest that the contamination is apparently slow, because the ions release by the tailing dump are continuously removed in rivers and washed by rains. Even less toxic, iron was found in huge amount $(357,869 \mathrm{mg} / \mathrm{kg})$ in the tailing dump, but it accumulates also in the surrounding soils $(493,500 \mathrm{mg} / \mathrm{kg})$. Iron can also bind the other ions and create a toxic environment. Manganese was found as traces in the tailing dump, but it reached $661 \mathrm{mg} / \mathrm{kg} 30 \mathrm{~m}$ far from this dump. Similar concentrations of zinc were measured both in the tailing dump (432 mg/kg) and at 30 $\mathrm{m}$ far from it ( $421 \mathrm{mg} / \mathrm{kg}$ ). Ba increased from $14 \mathrm{mg} / \mathrm{kg}$ to $537 \mathrm{mg} / \mathrm{kg}$, but this element was proven not to be toxic to plants. Calcium also increased much starting from the dump ( $832 \mathrm{mg} / \mathrm{kg})$ to $(12,305 \mathrm{mg} / \mathrm{kg})$ in the neighborhood.

\section{Conclusions}

In this work we have determined the content of some heavy metal ions ( $\mathrm{Fe}, \mathrm{Cu}, \mathrm{Zn}$ and $\mathrm{Mn}$ ) and three mineral nutrients ( $\mathrm{Ca}, \mathrm{Mg}$ and $\mathrm{K}$ ) in silver fir and European beech wood collected from two differently polluted sites on Tarnita mining area. The whole wood cores were collected at 1.3 $\mathrm{m}$ height, the metal-containing ash analyzed by atomic absorption spectrometry. A high variation in heavy metals concentrations between individual trees was noticed. The $t$-test and the Mann-Whitney $U$ test indicated some differences between the contents of the heavy metal and mineral nutrients in silver fir and European beech situated on the two sampling sites. Results are concordant with those reported by other authors. The Mn content was higher near the dump, for both species, but the difference was statistically significant only for beech tree. The $\mathrm{Zn}$ content was lower in the polluted site near a tailing dump than in a less polluted one, situated $6 \mathrm{~km}$ far from the first one, for both species, but was significant only for silver fir. Furthermore, the content of $\mathrm{Ca}$ and $\mathrm{Mg}$ was higher for the less polluted site, for both species, suggesting a better state of nutrition for these trees than for those located near the dump. As for silver fir, the content of calcium and magnesium was negatively correlated with the diameter of the trees collected from both sites.

There was found a specific relationship between the contamination level with heavy metals of Tarnikg area and the accumulation of some of them in the forest trees. Although the wood trees studied here were affected by heavy metal pollution, they also reacted against it by limiting metal ion uptake. Moreover, due to their long-life span, even the trees located $6 \mathrm{~km}$ far from the polluted tailings dump could have been contaminated. In addition, these toxic heavy metals seem to interfere with the metabolism of the nutrients in the woody species.

Acknowledgments: The authors are grateful to Dr. Nicolai Olenici for statically interpretation of results. The financial support from the UEFISCDI PN-IIIP4-ID-PCE-2016-0376 Project, Contract 56/2017 is gratefully acknowledged. GD acknowledges the Partnership Project Metafore PN-II-PT-PCCA-2013-4-1149 (Contract 107/2014), which was the beginning of this research.

\section{References}

1. HUDSON-EDWARDS, K.A., JAMIESON, H.E., LOTTERMOSER, B.G., Elements, 7, no. 6, 2011, p. 375.

2. TODIRASCU-CIORNEA, E., DUMITRU, G., SANDU, I., Rev. Chim. (Bucharest), 69, no. 8, 2018, p. 2160.

3. TODIRASCU-CIORNEA, E., DUMITRU, G., ZAHARIA, M., DROCHIOIU, G., SANDU, I., Rev. Chim. (Bucharest), 69, no. 2, 2018, p. 449. 
4. NECULA, R., GILLE, E., DIRTU, A.C., SANDU, I., GRADINARU, V.R., PETCU, A., DROCHIOIU, G., Rev. Chim. (Bucharest), 69, no. 7, 2018, p. 1682.

5. DROCHIOIU, G., MURARIU, M., PETRE, A.B., MANEA, M., PRZYBYLSKI, M., Rev. Chim. (Bucharest), 58, no. 3, 2007, p. 311.

6. IONCE, A., Present Environ. Sust. Develop., 3, no. 1, 2009, p. 263. 7. STUMBEA, D., CHICOS, M., An. St. Univ. A.I. Cuza lasi, S. 2, Geology, 58, no. 1, 2012, p. 23.

8. STUMBEA, D., Environ. Sci. Pollut. Res., 20, no. 11, 2013, p. 7643. 9. CIORNEA, E., BOZ, I., IONEL, E., COJOCARU, S. I., DUMITRU, G., Turk. J. Biol., 39, no. 4, 2015, p. 624.

10. CHICOS, M.M., DAMIAN, G., STUMBEA, D., BUZGAR, N., UNGUREANU, T., NICA, V., IEPURE, G. Carpath. J. Earth Env., 1, no. 1, 2016, p. 265.

11. CIORNEA, E., BOZ, I., IONEL, E., COJOCARU, S.I., DUMITRU, G. Turk. J. Biol., 39, no. 4, 2015, p. 624.

12. VOICA, C., KOVACS, M.H., DEHELEAN, A., RISTOIU, D., IORDACHE, A. Rom. J. Phys., 57, 2012, p. 1184.

13. LACATUSU, R., LACATUSU, A.R., Carpath. J. Earth Env., 3, no. 2, 2008, p. 115.

14. HARMANESCU, M., ALDA, L. M., BORDEAN, D.M., GOGOASA, I., GERGEN, I., Chem. Cent. J., 5, no. 1, 2011, p. 64.

15. LEVEI, E., FRENTIU, T., PONTA, M., SENILA, M., MICLEAN, M., ROMAN, C., CORDOS, E., Int. J. Environ. Anal. Chem., 89, no. 8-12, 2009, p. 635.

16. STAN, O.A., LUCACIU, A., FRONTASYEVA, M.V., STEINNES, E., New results from air pollution studies in Romania, in: Radionuclides and Heavy Metals in Environment, Springer, Rotterdam, 2001, p. 179.

17. GERGEN, I., HARMANESCU, M., Chem. Cent. J., 6, no. 1, 2012, p. 156.

18. LUPESCU, M., J. Hortic. Forest Biotech., 18, no. 2, 2014, p. 40.

19. BLACKWELL, K.J., SINGLETON, I., TOBIN, J.M., Appl. Microbiol. Biotechnol., 43, no. 4, 1995, p. 579.

20. CECAL, A., PALAMARU, I., POPA, K., CARAUS, I., RUDIC, V., GULEA, A., Isot. Environ. Health S. 35, no. 3, 1999, p. 213.

21. CHO, D.Y., LEE, S., PARK, S., CHUNG, A., J. Environ. Sci. Health A, 29, no. 2, 1994, p. 389.
22.*** Ord. 161 (2006). Ordin no. 161 of 16.02.2006: Normativ privind clasificarea calitãpi apelor de suprafapã în vederea stabilirii stãrii ecologice a corpurilor de apã (The norms on classification of surface water quality in order to establish the ecological status of water bodies). Monitorul Oficial 511 of 13.06.2006.

23. HAGEMEYER, J., SCHÄFER, H., Sci. Total Environ., 166, no. 1-3, 1995, p. 77.

24. NABAIS, C., FREITAS, H., HAGEMEYER, J., Sci. Total Environ., 232, no. 1-2, 1999, p. 33.

25. ADELOJU, S.B., Analyst, 114, no. 4, 1989, p. 455.

26. AKINYELE, I.O., SHOKUNBI, O.S., Food Chem., 173, 2015, p. 682. 27. MACFARLAND, T. W., YATES, J. M., Mann-Whitney U Test. In: Introduction to Nonparametric Statistics for the Biological Sciences Using R, Springer, Basel, 2016, p. 103.

28. STEFANESCU, R., BUTNARIU, A.E., ZAMFIRACHE, M.M., SURLEVA, A., CIOBANU, C.I., PINTILIE, O., DROCHIOIU, G., Carpath. J. Earth Env., 12, no. 1, 2017, p. 153.

29. PUNDYTE, N., BALTRENAITE, E., PEREIRA, P., PALIULIS, D., J. Environ. Eng. Landsc., 19, no.1, 2011, p. 34.

30. DROCHIOIU, G., SURLEVA, A., ILIEVA, D., TUDORACHI, L., NECULA, R., International Multidisciplinary Scientific GeoConference: SGEM: Surveying Geology \& mining Ecology Management, 2, 2016, p. 525.

31. ZAHARIA, M., DROCHIOIU, G., ILIEVA, D., BUTNARIU, A. E., SURLEVA, A., SGEM2017 Vienna GREEN Conference Proceedings, 17, no. 43, 2017, p. 397. DOI: 10.5593/sgem2017H/43/S19.050

32. ENDERS, A., LEHMANN, J., Commun. Soil Sci. Plant Anal., 43, no. 7, 2012, p. 1042.

33. OPYDO, J., ZEMBRZUSKI, W., Chem. Anal. (Warsaw), 38, 1993, p. 823.

34. ROTHPFEFFER, C., KARLTUN, E., Biomass Bioenerg., 31, no.10, 2007, p. 717.

35. MARKOVIC, D.M., MILOSEVIC, I.R., VILOTIC, D., Environ. Sci. Pollut. Res., 20, 2013, p. 136.

36. SZASZ-LEN, A.M., HOLONEC, L., PAMFIL, D., ProEnvironment, 9 , 2016, p. 41.

37. SAWIDIS, T., BREUSTE, J., MITROVIC, M., PAVLOVIC, P., TSIGARIDAS, K., Environ. Pollut., 159, no. 12, 2011, p. 3560. 38. MEERTS, P., Ann. Forest Sci., 59, no. 7, 2002, p. 713.

Manuscript received: 26.09 .2018 